Original research article

\title{
Alterations of glycaemia, insulin resistance and body mass index within the $C$-peptide optimal range in non-diabetic patients
}

\author{
Vladimír Kron ${ }^{1,6}$ *, Miroslav Verner ${ }^{2,5}$, Pavel Smetana ${ }^{1}$, Jana Janoutová ${ }^{3}$, Vladimír Janout ${ }^{4}$, \\ Karel Martiník ${ }^{6}$ \\ ${ }^{1}$ University of South Bohemia, Faculty of Agriculture, Department of Food Biotechnologies and Agricultural Products Quality, České Budějovice, \\ Czech Republic \\ ${ }^{2}$ Hospital of České Budějovice, a. s., Central Laboratories, České Budějovice, Czech Republic \\ ${ }^{3}$ Palacký University Olomouc, Faculty of Health Sciences, Department of Healthcare Management, Olomouc, Czech Republic \\ ${ }^{4}$ Palacký University Olomouc, Faculty of Health Sciences, Center for Research and Science, Olomouc, Czech Republic \\ ${ }^{5}$ University of South Bohemia, Faculty of Health and Social Sciences, Institute of Laboratory Diagnostics, České Budějovice, Czech Republic \\ ${ }^{6}$ Center for Metabolic Assessment of prof. MUDr. Karel Martiník, DrSc., s.r.o., Hradec Králové, Czech Republic
}

\begin{abstract}
The study focused on changes or cut-offs of glycaemia, insulin resistance and body mass index within the $C$-peptide reference range (260-1730 pmol/l). The metabolic profile of individuals in the Czech Republic without diabetes $(n=3186)$ was classified by whiskers and quartiles of $C$-peptide into four groups with the following ranges: 290-510 $(n=694), 511-710(n=780), 711-950(n=720)$ and 951-1560 pmol/1 $(n=673)$. Fasting levels of glucose, insulin, HOMA IR (Homeostasis Model Assessment for Insulin Resistance) and BMI (body mass index) were compared by a relevant C-peptide range. Participants taking medication to control glycaemia were excluded. The evaluation involved correlations between $C$-peptides and the above parameters, $F$-test and $t$-test. Changes in glucose levels (from 5.3 to $5.6 \mathrm{mmol} / \mathrm{l}$ ) between the groups were lower in comparison to insulin, which reached relatively greater changes (from 4.0 to $14.2 \mathrm{mIU} / \mathrm{l}$ ). HOMA IR increased considerably with growing C-peptide concentrations (0.9, 1.5, 2.2 and 3.5) and BMI values showed a similar trend (28.3, 31.0, 33.6 and 37.4). Considerable changes were observed for insulin (5.2 mIU/1, 57.8\%) and HOMA IR (1.3, 61.3\%) between groups with C-peptide ranges of 711-950 and 951-1560 pmol/l. Although correlations involving C-peptide, insulin, glucose and BMI seemed to be non-significant (up to $r_{\mathrm{xy}}=0.25$ ), the mean values of insulin, HOMA IR and BMI showed statistically significant changes between all groups with various $C$-peptide concentrations $(p \leq 0.001)$.

Generally, most important differences appeared in glucose metabolism and body mass index between C-peptide ranges of 711-950 and 951-1560 pmol/l.

Absolute and relative changes of $C$-peptide concentrations are possible to use for the assessment of glucose regulatory mechanism. The spectrum of investigated parameters could be a useful tool to prevent the risks linked with the alterations of glycaemia.
\end{abstract}

Keywords: Body mass index; C-peptide; Glucose; Insulin resistance

\section{Highlights:}

- Glycaemia, insulin resistance and body mass index already change within the $C$-peptide reference range.

- Major changes in glucose metabolism and body mass index values appeared between C-peptides ranges of 711-950 and 951-1560 pmol/1.

- The mean values of insulin, HOMA IR and BMI showed statistically significant differences between all groups with growing C-peptide concentrations.

\section{Introduction}

C-peptide constitutes a segment of insulin synthesis. Proteolysis of proinsulin leads to release of equimolar amounts of insulin and C-peptide (Toffolo et al., 1995). Therefore, C-peptide is considered an equivalent to insulin production and reflects beta cell function. However, C-peptide has also been reported to have its own biological activity and has been known to stimulate glucose transport via a mechanism independent of insulin receptors (Zierath et al., 1996). The basic feature of C-peptide, commonly used in the detection, is its half-life (Palmer, 2009). Unlike insulin, C-peptides are not degraded by the liver and coexist in secretory granules from where they are

\footnotetext{
* Corresponding author: Vladimír Kron, Center for Metabolic Assessment of prof. MUDr. Karel Martiník, DrSc., s.r.o., Bratří Štefanů 895, 500 03, Hradec Králové, Czech Republic; e-mail: vladimir.daniel.kron@gmail.com http://doi.org/10.32725/jab.2020.018
}

Submitted: 2020-07-17 • Accepted: 2020-11-28 • Prepublished online: 2020-12-08

J Appl Biomed 18/4: 136-142 • EISSN 1214-0287 • ISSN 1214-021X

(c) 2020 The Authors. Published by University of South Bohemia in České Budějovice, Faculty of Health and Social Sciences.

This is an open access article under the CC BY-NC-ND license. 
simultaneously released into the capillary loop (Cardellini et al., 2017). Therefore, the determination of C-peptide can be used to distinguish between type 1 and type 2 diabetes mellitus (Pujia et al., 2017).

The association between C-peptide and glycaemia parameters has been addressed in many studies worldwide. Wang et al. (2019) used fasting C-peptide concentrations as biomarkers of insulin production or resistance. Recorded quartiles of C-peptide were used to establish individual cut-offs for possible incidence of cardiovascular risks. Similarly, Christensen et al. (2019) evaluated a covariance between fasting C-peptide and glucose and found that $C$-peptide concentrations were associated with greater variability of glycaemia. According to Smith et al. (2019), correct C-peptide interpretation should be supplemented with simultaneous blood glucose measurements. Pinckney et al. (2016) focused on possible regression between glycaemia parameters and C-peptide concentration. They tested possible associations between C-peptide levels, glycaemia variability and hypoglycaemic events.

Although many authors have agreed on a need for C-peptide and glycaemia analyzes, another question is the optimal range and cut-offs for glycaemia alterations. Buse et al. (2008) mentioned that optimal fasting $C$-peptide levels should be from 0.5 to $2.0 \mathrm{ng} / \mathrm{ml}$ (165.5-662.2 pmol/1). Pagana and $\mathrm{Pa}-$ gana (2013) used an optimal range of 0.78-1.89 ng/ml (260$620 \mathrm{pmol} / \mathrm{l}$ ) for fasting C-peptide levels to determine abnormal glycaemia parameters. Concentrations above $2.0 \mathrm{ng} / \mathrm{ml}$ (662 pmol/l) were considered increased. Yosten et al. (2014) used a narrower range of physiological fasting C-peptide plasma concentrations of 0.9 to $1.8 \mathrm{ng} / \mathrm{ml}$ (298.0-596.0 pmol/1). Wahren (2004) recommended higher reference values (1.1-4.4 ng/ml or 463.5-1456.8 pmol/1) of fasting C-peptide.

Slight differences may be found between recommendations by local authors, laboratories and manufacturers of analytical devices. The Diagnostic Products Corporation, a company using chemiluminescent immunoassays to detect C-peptide concentrations, recommended an optimal range of 364-1655 pmol/l (S-C-peptide analyze, 2020). A manufacture of electro-chemiluminescence immunoassay devices set the optimal C-peptide level at $520 \pm 169 \mathrm{pmol} / \mathrm{l}$ and mentioned that the concentration of $C$-peptide, although 3-fold higher after stimulation, is still physiological (C-peptide serum analyze, 2020). Mayo Medical Laboratories consider optimal reference values to be $1.4-4.4 \mathrm{ng} / \mathrm{ml}$ (463.5-1456.8 pmol/l) (Test ID: CPR, C-Peptide serum, 2020).

\section{Material and methods}

Metabolic profiles of correlative study were collected in the Czech Republic from 2009 until 2017 and all participants gave consent to anonymous data analysis. This evaluation involves the experience of metabolic institute and primarily didn't prefer any subjects under special, social, cultural fitness conditions. The patients included were aged $15-78(n=3186)$ to ensure an optimal profile of the population. Individuals receiving therapy or supplements to treat abnormal lipid or glucose metabolism were excluded. After summaries of information on the subjects had been prepared, all samples were properly processed (centrifuging, serum preparation etc.) and analyzed.

C-peptides and insulin concentrations were analyzed by regulatory impact assessment methodology from the plasma of fasting subjects. Glucose concentrations were determined on acid-base analyzers. All serum biochemical parameters for the tests were provided by the manufacturers' instructions with a strict following of the measurement continuity (Roche Diagnostics, Abbott Laboratories).

\section{Methods}

Concentrations of C-peptide, glucose and insulin were analyzed using the oral glucose-tolerance test (OGTT) according to a valid methodology. Khan et al. (2018) also tested relationships between C-peptide and glycated haemoglobin, insulin and glucose in non-diabetic patients during the OGTT. Reference ranges of C-peptide (260-1730 pmol/l), glucose (3.9-5.6 mmol/l) and insulin (2.5-24.0 mIU/l) were adapted to the Czech Republic setting and have usually been mentioned as reference ranges (Methodology of glucose, total, HDL and LDL cholesterol, 2020).

Fasting C-peptide and glycaemia parameters (glucose and insulin) were evaluated to test basal metabolism. To consider alterations under physiological conditions, individuals with C-peptide concentrations below $260 \mathrm{pmol} / 1$ or above $1730 \mathrm{mmol} / \mathrm{l}$ were excluded. Also patients with glucose levels suggestive of hypoglycemia and parameters of diabetes (below $3.9 \mathrm{mmol} / \mathrm{l}$ or above $7.2 \mathrm{mmol} / \mathrm{l}$ ), were removed from the study. Insulin resistance was assessed by the HOMA IR score (Homeostasis Model Assessment for Insulin Resistance) based on insulin and glucose concentrations. HOMA IR cut-off was set at 3.63 , considered a signal of glucose metabolism alterations within the Czech population (Horáková et al., 2019). A body mass index (BMI) reference range of $20.0-24.9 \mathrm{~kg} / \mathrm{m}^{2}$ (normal weight) was calculated by Svačina and Bretšnajdrová (2003).

\section{Statistical analysis}

All parameters (glucose, insulin, HOMA IR, age, BMI) were divided by $C$-peptide quartiles (Table 1 , Chart 1 ) to be relevant for individual patients.

Evaluated range of C-peptides involved lower (290 pmol/1) and upper (1560 pmol/l) limits. Li et al. (2015) used similar methods to compare physiological parameters (linked with cardio-vascular diseases and lipoproteins) within groups created by $\mathrm{C}$-peptide quartiles. At first, basic statistical parameters were calculated for all groups: number of values (n), arithmetic mean $(\bar{x})$, standard deviation $\left(\mathrm{S}_{\mathrm{x}}\right)$, minimum (Min) and maximum (Max). Lower whiskers, upper whiskers, quartiles and medians identified data distribution. To test the possible association between variables, the Pearson's correlation coefficients $\left(r_{\mathrm{xy}}\right)$ were determined with limits of significance $r_{\mathrm{xy}}=$ 0.1 : low; $r_{\mathrm{xy}}=0.3$ : middle and $r_{\mathrm{xy}}=0.5$ : high. The F-test (with quantile $F_{0.975}$ ) was performed to test the quality of variance and select the right type of the $t$-test. The criteria for statistical significance $\left(\mathrm{H}_{0}\right.$ vs $\left.\mathrm{H}_{a}\right)$ were set as follows: $0.05>p \geq 0.01$ (significant $^{*}$ ) $0.01>p>0.001$ (moderately significant ${ }^{* *}$ ) and highly significant $\left.{ }^{* *}\right)(p \leq 0.001)$. The calculation of basic data was performed by Microsoft Excel (MS Office - Excel version 16) and equally this software was used to prepare the file for subsequent analysis (the exclusion of patients using dietary supplements, the ranges of C-peptide, glycaemia, insulin, HOMA IR, age, BMI). StatPlus (version 7, L.E. 6.9.1.0) provided the information about the data distribution (quartiles, histogram), possible relationships or the differences (the correlations, $F$-test, $t$-test). Software Statistica (version 12) confirmed the statistical results and enabled the graphical process of values. To maintain the quantity and data distribution, the file was not divided by gender and critical values of characteristics were set for both genders and not separately. 
Table 1. Data distribution of C-peptides (pmol/l)

\begin{tabular}{lr}
\hline Minimum & 260 \\
Lower whisker & 290 \\
Q1 & 519 \\
Median & 710 \\
Q3 & 960 \\
Upper whisker & 1560 \\
Maximum & 1730 \\
\hline
\end{tabular}

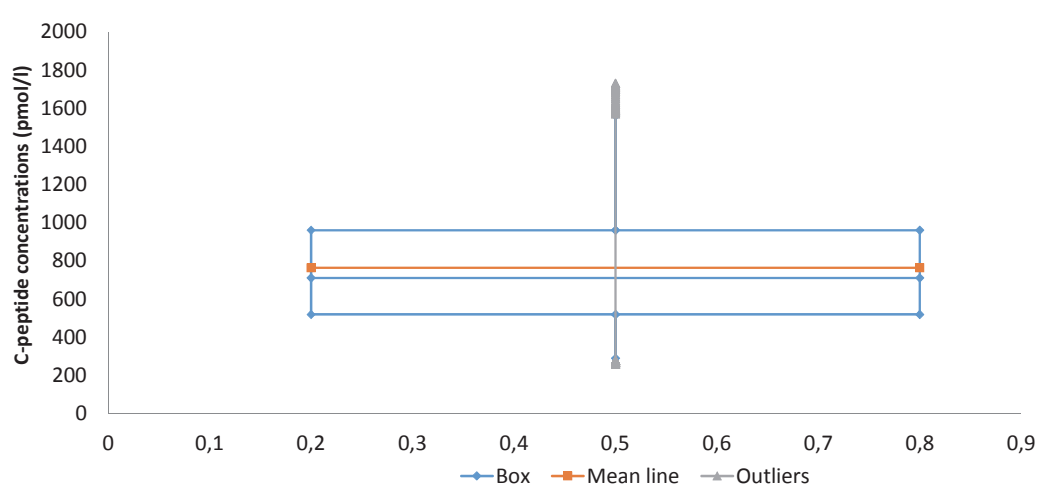

Chart 1. Data distribution of C-peptides (pmol/l)

iological range $(5.6 \mathrm{mmol} / \mathrm{l})$. The difference in glucose (up to $0.3 \mathrm{mmol} / \mathrm{l}$ ) between the groups with $\mathrm{C}$-peptide concentration ranging from 290 to $1560 \mathrm{pmol} / \mathrm{l}$ was small. Naturally, the highest level of glucose $(5.6 \mathrm{mmol} / \mathrm{l})$ was reached in the group with a C-peptide range of 951-1560 pmol/l. Insulin concentrations showed a tendency similar to that of glucose and increased with higher $\mathrm{C}$-peptides ranges. However, insulin levels showed relatively greater changes in comparison to glucose, ranging from 4.0 to $14.2 \mathrm{mIU} / \mathrm{l}$. The highest mean concentration of insulin (14.2 mIU/l) was observed in the group with a C-peptides range of 951-1560 pmol/l, representing more than twice the concentration in the group with a $C$-peptide

Table 2. Statistical characteristics of the groups with various ranges of $C$-peptide

\begin{tabular}{|c|c|c|c|c|c|c|}
\hline \multicolumn{7}{|c|}{ Individuals with C-peptide concentration of $290-510 \mathrm{pmol} / 1$} \\
\hline Characteristics & C-peptide (pmol/l) & Age (y) & Insulin (mIU/l) & Glucose $(\mathrm{mmol} / \mathrm{l})$ & HOMA IR & BMI $\left(\mathrm{kg} / \mathrm{m}^{2}\right)$ \\
\hline $\mathrm{n}$ & 694 & 694 & 694 & 694 & 694 & 694 \\
\hline $\bar{x}$ & 409.4 & 39 & 4.0 & 5.3 & 0.9 & 28.3 \\
\hline$S_{x}$ & 65.4 & 11 & 1.4 & 0.5 & 0.4 & 5.2 \\
\hline Min & 290.0 & 15 & 1.0 & 3.9 & 0.2 & 14.5 \\
\hline $\operatorname{Max}$ & 510.0 & 78 & 14.0 & 7.0 & 3.5 & 46.0 \\
\hline \multicolumn{7}{|c|}{ Individuals with C-peptide concentration of 511-710 pmol/1 } \\
\hline $\mathrm{n}$ & 780 & 780 & 780 & 780 & 780 & 780 \\
\hline $\bar{x}$ & 614.5 & 40 & 6.2 & 5.3 & 1.5 & 30.1 \\
\hline $\mathrm{S}_{\mathrm{x}}$ & 56.2 & 11 & 2.4 & 0.5 & 0.6 & 6.0 \\
\hline Min & 511.0 & 15 & 1.4 & 3.9 & 0.3 & 17.1 \\
\hline Max & 710.0 & 78 & 29.9 & 7.0 & 7.8 & 56.9 \\
\hline \multicolumn{7}{|c|}{ Individuals with C-peptide concentration of $711-950 \mathrm{pmol} / 1$} \\
\hline $\mathrm{n}$ & 720 & 720 & 720 & 720 & 720 & 720 \\
\hline $\bar{x}$ & 825.2 & 41 & 9.0 & 5.4 & 2.2 & 33.6 \\
\hline $\mathrm{S}_{\mathrm{x}}$ & 69.3 & 12 & 3.6 & 0.6 & 0.9 & 6.1 \\
\hline Min & 713.0 & 15 & 1.2 & 3.9 & 0.3 & 17.7 \\
\hline Max & 950.00 & 78 & 37.0 & 7.2 & 8.9 & 58.9 \\
\hline \multicolumn{7}{|c|}{ Individuals with C-peptide concentration of 951-1560 pmol/1 } \\
\hline$n$ & 673 & 673 & 673 & 673 & 673 & 673 \\
\hline $\bar{x}$ & 1175.0 & 42 & 14.2 & 5.6 & 3.5 & 37.4 \\
\hline $\mathrm{S}_{\mathrm{x}}$ & 156.8 & 12 & 5.5 & 0.6 & 1.4 & 6.3 \\
\hline Min & 953.0 & 15 & 2.00 & 3.9 & 0.4 & 18.5 \\
\hline Max & 1550.0 & 78 & 38.3 & 7.2 & 10.4 & 61.8 \\
\hline
\end{tabular}




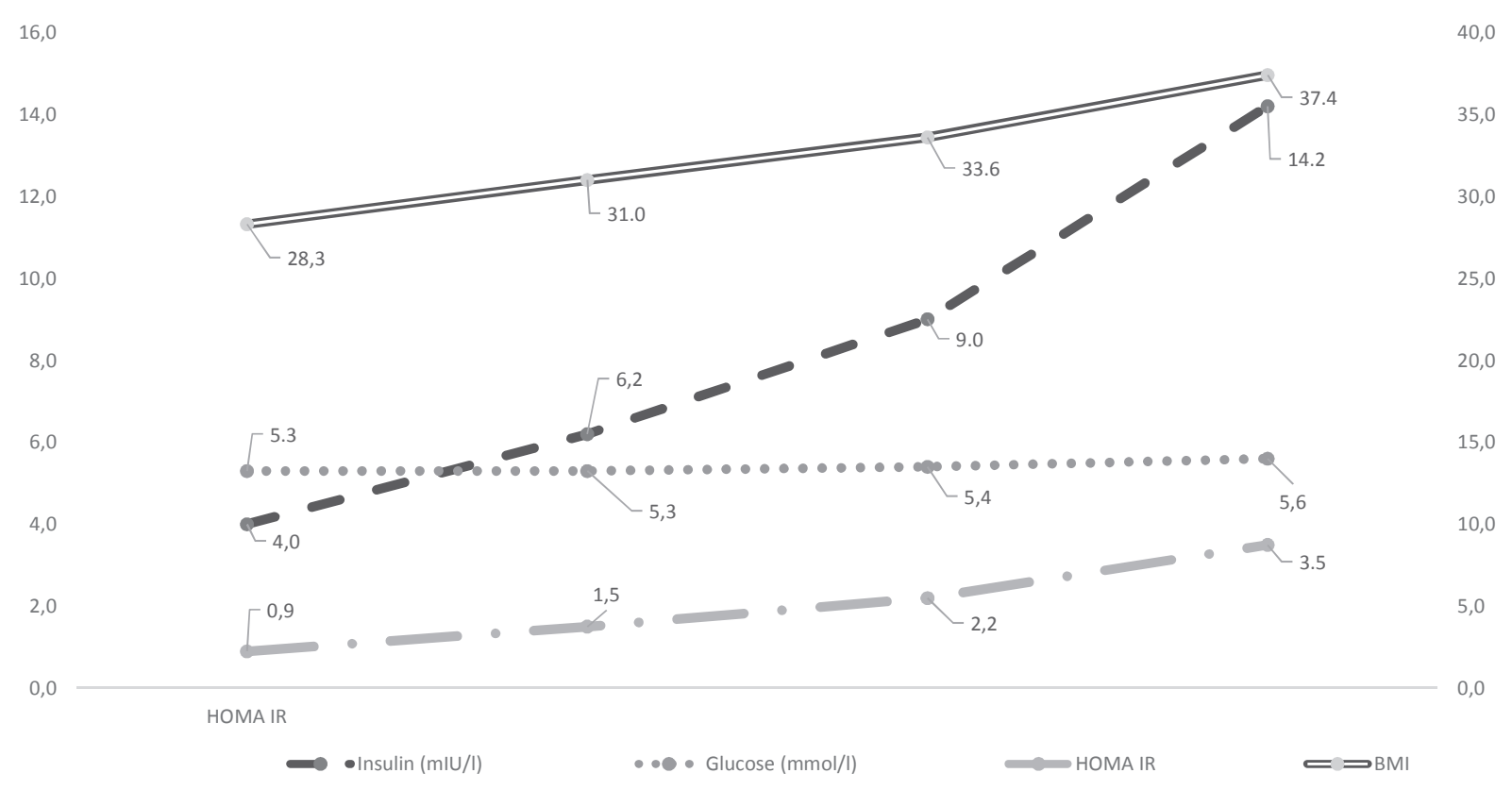

Chart 2. Alterations in glycaemia parameters and BMI for various ranges of C-peptide

Table 3. Comparison of mean values for the groups with various $C$-peptide ranges with the reference ranges

\begin{tabular}{lcccc}
\hline C-peptide range $(\mathrm{pmol} / \mathrm{l})$ & Insulin $(\mathrm{mIU} / \mathrm{l})$ & Glucose $(\mathrm{mmol} / \mathrm{l})$ & HOMA IR & BMI $\left(\mathrm{kg} / \mathrm{m}^{2}\right)$ \\
\hline $290-510$ & 4.0 & 5.3 & 0.9 & 2.5 \\
$511-710$ & 6.2 & 5.3 & 2.3 & 31.0 \\
$711-950$ & 9.0 & 5.4 & 3.5 & 33.6 \\
$951-1560$ & 14.2 & 5.6 & $<3.63$ & 37.4 \\
Reference range of values & $2.5-24.0$ & $3.9-5.6$ & $20.0-24.9$ \\
\hline
\end{tabular}

range of 290-510 pmol/l. Also the HOMA IR values increased with higher $C$-peptide ranges. Changes in HOMA IR showed a tendency similar to that of insulin $(0.9,1.5,2.2$ and 3.5$)$ and increased more than three-fold as C-peptide concentration increased from 290 to $1560 \mathrm{pmol} / \mathrm{l}$. BMI values exceeded the optimal range regardless of $\mathrm{C}$-peptide ranges. The mean BMI value $\left(28.3 \mathrm{~kg} / \mathrm{m}^{2}\right)$ for a C-peptide range of $290-510 \mathrm{pmol} / 1$ was already above the BMI physiological cut-off $\left(24.9 \mathrm{~kg} / \mathrm{m}^{2}\right)$. However, the BMI values showed a steady increase (28.3, 31.0, 33.6 and $37.4 \mathrm{~kg} / \mathrm{m}^{2}$ ).
Considerable changes in insulin metabolism were recorded especially between groups with C-peptide ranges of 711-950 and 951-1560 pmol/l. The differences in insulin concentrations (5.2 mIU/l) and HOMA IR (1.3) between the two groups reached $57.8 \%$ and $61.3 \%$.

To test possible correlations between C-peptide, glycaemia and insulin resistance parameters and BMI values, the Pearson's correlation coefficients $\left(r_{\mathrm{xy}}\right)$ were determined (Table 4$)$.

Table 4. Correlations between C-peptide and glycaemia parameters, HOMA IR and BMI

\begin{tabular}{lcccc}
\hline Pearson's correlation coefficients $\left(r_{\mathrm{xy}}\right)^{(p<0.05)}$ & Insulin $(\mathrm{mIU} / \mathrm{l})$ & Glucose $(\mathrm{mmol} / \mathrm{l})$ & HOMA IR & BMI $\left(\mathrm{kg} / \mathrm{m}^{2}\right)$ \\
\hline C-peptide $(\mathrm{pmol} / \mathrm{l})$ & 0.19 & 0.25 & 0.18 & 0.03 \\
\hline
\end{tabular}

All correlations involving C-peptide and metabolic parameters (insulin, glucose, HOMA IR and BMI) seemed to be non-significant (up to $r_{\mathrm{xy}}=0.3$ ). A higher correlation coefficient was only found between $C$-peptide and glucose $\left(r_{\mathrm{xy}}=\right.$ $0.25)$. Subsequent regression analysis were not performed due to lower results of $r_{\text {xy }}$ (up to 0.5). The F-test was used to test the equality of variance between groups with different $C$-peptide ranges (Table 5).
Higher frequency of statistically significant changes $(p<0.05)$ was recorded in the variances of BMI between C-peptide ranges of 511-710 and 711-950 pmol/1. Similarly, the variances of BMI in the highest group of C-peptides (950-1560 pmol/l) differed in comparison to the lower group (711-950 pmol/l). Based on the F-test results, the right type of $t$-test was determined to compare the values within groups with various $C$-peptide concentration ranges (Table 6 ). 
Table 5. Results of the F-test/critical values between insulin, glucose, HOMA IR and BMI for various ranges of C-peptide concentrations (pmol/l)

\begin{tabular}{|c|c|c|c|}
\hline Insulin (mIU/l) & C-peptide 290-510 & C-peptide 511-710 & C-peptide 711-950 \\
\hline C-peptide $511-710$ & $0.36 / 0.89$ & - & \\
\hline C-peptide 711-950 & & $0.44 / 0.89$ & - \\
\hline C-peptide 951-1560 & & & $0.42 / 0.88$ \\
\hline Glucose $(\mathrm{mmol} / \mathrm{l})$ & C-peptide $290-510$ & C-peptide $511-710$ & C-peptide 711-950 \\
\hline C-peptide $511-710$ & $0.77 / 0.89$ & - & \\
\hline C-peptide 711-950 & & $0.91 * / 0.89$ & - \\
\hline C-peptide 951-1560 & & & $0.82 / 0.88$ \\
\hline HOMA IR & C-peptide 290-510 & C-peptide $511-710$ & C-peptide 711-950 \\
\hline C-peptide $511-710$ & $0.34 / 0.88$ & - & \\
\hline C-peptide 711-950 & & $0.44 / 0.88$ & - \\
\hline C-peptide 951-1560 & & & $0.40 / 0.88$ \\
\hline BMI value $\left(\mathrm{kg} / \mathrm{m}^{2}\right)$ & C-peptide 290-510 & C-peptide $511-710$ & C-peptide 711-950 \\
\hline C-peptide $511-710$ & $0.75 / 0.89$ & - & \\
\hline C-peptide 711-950 & & $0.95 * / 0.88$ & - \\
\hline C-peptide 951-1560 & & & $0.95 * / 0.88$ \\
\hline
\end{tabular}

Table 6. Results of the $t$-test/critical values between insulin, glucose, HOMA IR and BMI for various ranges of C-peptide concentrations (pmol/l)

\begin{tabular}{|c|c|c|c|}
\hline Insulin (mIU/l) & C-peptide 290-510 & C-peptide 511-710 & C-peptide 711-950 \\
\hline C-peptide $511-710$ & $21.34^{* * *} / 1.96$ & - & \\
\hline C-peptide 711-950 & & $17.75^{* * *} / 1.96$ & - \\
\hline C-peptide 951-1560 & & & $20.90^{* * *} / 1.96$ \\
\hline Glucose (mmol/l) & C-peptide 290-510 & C-peptide $511-710$ & C-peptide 711-950 \\
\hline C-peptide $511-710$ & $2.28^{* *} / 1.96$ & - & \\
\hline C-peptide 711-950 & & $3.64^{* *} / 1.96$ & - \\
\hline C-peptide 951-1560 & & & $4.00^{* *} / 1.96$ \\
\hline HOMA IR & C-peptide 290-510 & C-peptide $511-710$ & C-peptide 711-950 \\
\hline C-peptide $511-710$ & $20.44^{* * *} / 1.96$ & - & \\
\hline C-peptide 711-950 & & $17.60^{* * *} / 1.96$ & - \\
\hline C-peptide 951-1560 & & & $20.83^{* * *} / 1.96$ \\
\hline BMI value $\left(\mathrm{kg} / \mathrm{m}^{2}\right)$ & C-peptide 290-510 & C-peptide $511-710$ & C-peptide 711-950 \\
\hline C-peptide 511-710 & $9.10^{* * *} / 1.96$ & - & \\
\hline C-peptide 711-950 & & $8.38^{* * *} / 1.96$ & - \\
\hline C-peptide 951-1560 & & & $11.34^{* * *} / 1.96$ \\
\hline
\end{tabular}

Values of insulin and HOMA IR showed statistically significant changes between all groups with various $C$-peptide concentrations. The mean concentrations of glucose also differed between the groups $(p \leq 0.01)$. Similar statistical results with high significance $(p \leq 0.001)$ were observed for BMI values in the groups of $C$-peptides.

\section{Discussion}

Glucose levels in the tested samples (5.3, 5.3, 5.4 and $5.6 \mathrm{mmol} / \mathrm{l}$ ) correspond with results in non-diabetic patients (5.4 mmol/l) in the Czech Republic for the year 2018 regard- less of C-peptide ranges. The levels of insulin (4.0, 6.2, 9.0, $14.2 \mathrm{mIU} / \mathrm{l})$ differ slightly in comparison to concentrations reached in the same survey (8.8-9.4 $\mathrm{mIU} / \mathrm{l})$. However, the mean level of insulin (9.1 mIU/l) is similar to that in the group with a C-peptide range of 711-950 pmol/1 (9.00 mIU/1). Similarly, the range of BMI values seems to be wider (from 28.3 to $37.4 \mathrm{~kg} / \mathrm{m}^{2}$ ) but approaching that in Czech patients without diabetes in the year 2018 (from 32.8 to $33.3 \mathrm{~kg} / \mathrm{m}^{2}$ ) (Horáková et al., 2019).

Andrade et al. (2018) also came to similar conclusions regarding glycaemia changes in healthy individuals divided by the quartiles of $\mathrm{C}$-peptide. Although their assessment included younger patients (aged 30), the differences $(p<0.001)$ were 
already recorded between quartiles of BMI (25.8, 26.6, 27.1 and $\left.28.3 \mathrm{~kg} / \mathrm{m}^{2}\right)$. Glucose values showed only slight changes by the quartiles $(4.9,4.8,4.9$ and $4.9 \mathrm{mmol} / \mathrm{l})$, similar to present study.

Thunander et al. (2012) also aimed to describe C-peptides in relation to age and BMI in a large population-based cohort survey of adults with newly diagnosed diabetes. C-peptide levels increased significantly with BMI and age. Haban et al. (2002) also confirmed a strong association between C-peptides and BMI $\left(r_{\mathrm{xy}}=0.52, p=0.004\right)$ but the relationship with fasting glucose was weaker $\left(r_{\mathrm{xy}}=0.40, p=0.029\right)$.

Results of cross-sectional studies not always showed the correlation between BMI and C-peptides. This non-association was partially explained by differences in body composition, with higher BMI not necessarily correlating to increasing body fat percentage potentially, affecting C-peptide levels (Siy et al., 2017).

The results including C-peptides and metabolic parameters (insulin, glucose, HOMA IR and BMI) in the physiological range seem to be lower (up to $r_{\mathrm{xy}}=0.25$ ) but these differences have appeared in studies of specific groups of patients as well. Higher correlation $\left(r_{\mathrm{xy}}=0.89\right)$ between HOMA IR and C-peptides was observed especially in patients at risk for type 2 diabetes (Gómez-Ambrossi et al., 2011). Bilal et al. (2010) tested insulin resistance parameters and C-peptide profiles and concluded that higher fasting levels of $\mathrm{C}$-peptide indicated insulin resistance, especially in obese patients. Francis et al. (2017) also evaluated fasting $C$-peptide and insulin concentrations and found a significant relationship $\left(r_{\mathrm{xy}}=0.65, p<0.001\right)$. However, this correlation considerably decreased during an OGTT test ( $r_{\mathrm{xy}}$ from 0.6 to 0.3 ).

Changes in insulin metabolism were recorded especially between the groups of $C$-peptides with concentration ranges of 711-950 and 951-1560 pmol/l. Also Shetty et al. (2017) investigated changes in glycaemia parameters with regard to C-peptide levels and found a cut-off of $3.6 \mathrm{ng} / \mathrm{ml}$ (1185.0 pmol/l). Juszczak et al. (2016) also investigated C-peptide levels possibly linked with the development of diabetes and determined the upper limit as $1.28 \mathrm{nmol} / \mathrm{l}(1280 \mathrm{pmol} / \mathrm{l})$.

\section{Conclusions}

Glycaemia, insulin resistance and BMI already change within the C-peptide optimal range. Major changes in glycaemia metabolism and BMI appeared between $C$-peptides ranges of 711-950 and 951-1560 pmol/l. Based on results of the present study and some authors' conclusions, it is possible to recommend $C$-peptide as a signal of glycaemia, insulin resistance and BMI changes. On the base of mentioned results, $C$-peptide was considered as a crucial parameter of metabolic assessments and the part of preventive procedures during the therapy of metabolic syndrome.

\section{Conflict of interests}

The authors have no conflict of interests to declare.

\section{Acknowledgements}

Funding source: This work was supported by MZe NAZV QK1910174.

\section{Abbreviations}

HOMA IR (Homeostasis Model Assessment for Insulin Resistance), BMI (Body Mass Index).

\section{References}

Andrade RLM, Gigante DP, de Oliveira IO, Horta BL (2018). C-peptide and cardiovascular risk factors among young adults in a southern Brazilian Cohort. BMC Endocr Disord 18: 80. DOI: 10.1186/s12902-018-0308-5.

Bilal A, Basanagouda SP, Thaseen A (2010). Significance of C-peptide in type 2 diabetics - a study in the North Karnataka population of India. Al Ameen J Med Sci. 3: 65-78.

Buse JB, Polonsky KS, Burant CF (2008). Type 2 diabetes mellitus. In: Kronenberg HM, Melmed S, Polonsky KS, Larsen PR. Williams Textbook of Endocrinology. Elsevier Saunders, Philadelphia, pp. 1329-1391.

C-peptide serum analyze (2020). Manual of recommendations of IKEM. [online] [cit. 2020-07-15]. Available at: https://www2.ikem. cz/plm_lp/_LP_05206-L0000006.htm

Cardellini M, Farcomeni A, Ballanti M, Morelli M, Davato F, Cardolini I, et al. (2017). C-peptide: a predictor of cardiovascular mortality in subjects with established atherosclerotic disease. Diabetes Vasc Dis Res 14: 395-399. DOI: $10.1177 / 1479164117710446$.

Christensen MB, Gaede P, Hommelc E, Gotfredsen A, Nørgaard K (2019). Glycaemic variability and hypoglycaemia are associated with C-peptide levels in insulin-treated type 2 diabetes. Diabetes Metab. 46: 61-65. DOI: 10.1016/j.diabet.2019.02.002.

Francis S, Padinjareveedu SC, Nesheera KK, Jacob J (2017). Fasting $C$-peptide correlated with fasting insulin and post glucose load $C$-peptides in young adults but the $C$-peptides could not be partitioned into groups with and without family history of type 2 diabetes mellitus. Int J Contemp Med Res 4: 467-472.

Gómez-Ambrosi J, Silva C, Galofré JC, Escalada J, Santos S, Gil MJ, et al. (2011). Body adiposity and type 2 diabetes: increased risk with a high body fat percentage even having a normal BMI. Obesity (Silver Spring) 19: 1439-44. DOI: 10.1038/oby.2011.36.

Haban P, Simoncic R, Zidekova E, Ozdin L (2002). Role of fasting serum $C$-peptide as a predictor of cardiovascular risk associated with the metabolic X-syndrome. Med Sci Monit 8: 175-179.

Horáková D, Štěpánek L, Janout V, Janoutová J, Pastucha D, Kollárová H, et al. (2019). Optimal homeostasis model assessment of insulin resistance (HOMA-IR) cut off in Czech population. Medicina 55: 158. DOI: 10.3390/medicina55050158.

Juszczak A, Pryse R, Schuman A, R Owen K (2016). When to consider a diagnosis of MODY at the presentation of diabetes. Br J Gen Pract 66: 457-459. DOI: 10.3399/bjgp16X685537.

Khan HA, Sobki SH, Ekhzaimy A, Khan I, Almusawi MA (2018). Biomarker potential of $C$-peptide for screening of insulin resistance in diabetic and non-diabetic individuals. Saudi J Bio Sci 27: 1729-1732. DOI: 10.1016/j.sjbs.2018.05.027.

Li Y, Meng L, Zheng L (2015). Association between serum C-peptide as a risk factor for cardiovascular disease and high-density lipoprotein cholesterol levels in nondiabetic individuals. PLoSOne 10: e112281. DOI: 10.1371/journal.pone.0112281.

Methodology of glucose, total, HDL and LDL cholesterol (2020). Department of Clinical Biochemistry and Diagnostics, University Hospital Hradec Králové. [online] [cit. 2020-07-15]. Available at: http://ukbd.fnhk.cz/seznam-metod.html

Pagana K, Pagana TJ (2013). Mosby's Manual of Diagnostic and Laboratory Tests. 5th ed. Elsevier Saunders, St. Louis.

Palmer, JP (2009). C-peptide in the natural history of type 1 diabetes. Diabetes Metab Res Rev 25: 325-328. DOI: 10.1002/ dmrr.943.

Pinckney A, Rigby MR, Keyes-Elstein L, Soppe CL, Nepom GT, Ehlers MR (2016). Correlation among hypoglycemia, glycemic variability, and $C$-peptide preservation after alefacept therapy in patients with type 1 diabetes mellitus: Analysis of data from the immune tolerance network T1 DAL trial. Clin Ther 38: 1327-1339. DOI: 10.1016/j.clinthera.2016.04.032.

Pujia A, Gazzaruso C, Montalcini T (2017). An update on the potential role of $C$-peptide in diabetes and osteoporosis. Endocrine 58: 408-12. DOI: 10.1007/s12020-017-1286-5. 
S-C-peptide analyze (2020). Manual of recommendations of DPC. Biolab company. [online] [cit. 2020-07-15]. Available at: https:// www.biolab-kt.cz/laboratorni-prirucka/HVEZDAAAWX.htm

Shetty V, Jain HR, Singh G, Parekh S, Shetty S (2017). C-peptide levels in diagnosis of diabetes mellitus: a case-control study. Int J Sci Stud 4: 7-13. DOI: 10.17354/ijss/2017/38.

Siy YP, Dampil OAC, Quimpo AJ (2017). The correlation of body mass index with fasting C-peptide levels of newly diagnosed type 2 diabetes mellitus Filipino patients. Philipp J Intern Med 55: 1-5.

Smith JD, Wijeratne N, McNeil A (2019). The need to feed? Is blood glucose above $8 \mathrm{mmol} / \mathrm{L}$ needed for the correct interpretation of C-peptide in patients with diabetes? Pathology 51: 114. DOI: 10.1016/j.pathol.2018.12.321.

Svačina Š, Bretšnajdrová A (2003). Diabetes and obesity, 1st ed. Prague: Maxdorf.

Test ID: CPR, C-Peptide serum (2020). Manual of Mayo Clinic Laboratories. [online] [cit. 2020-07-15]. Available at: https://www. mayocliniclabs.com/test-catalog/Clinical+and+Interpretive/8804

Thunander M, Törn C, Petersson Ch, Ossiansson B, Fornande J, Landin-Olsson M (2012). Levels of C-peptide, body mass index and age, and their usefulness in classification of diabetes in relation to autoimmunity, in adults with newly diagnosed diabetes in Kronoberg, Sweden. Eur J Endocrinol 166: 1021-1029. DOI: 10.1530/EJE-11-0797.

Toffolo G, De Grandi F, Cobelli C (1995). Estimation of beta-cell sensitivity from intravenous glucose tolerance test C-peptide data. Knowledge of the kinetics avoids errors in modeling the secretion. Diabetes 44: 845-854. DOI: 10.2337/diab.44.7.845.

Wahren J (2004). C-peptide: new findings and therapeutic implications in diabetes Clin Physiol Funct Imaging 24: 180-189. DOI: 10.1111/j.1475-097X.2004.00558.x.

Wang Y, Wan H, Chen Y, Xia F, Zhang W, Wang C, et al. (2019). Association of $C$-peptide with diabetic vascular complications in type 2 diabetes. Diabetes Metab 46: 33-40. DOI: 10.1016/j. diabet.2019.04.004.

Yosten GL, Maric-Bilkan C, Luppi P, Wahren J (2014). Physiological effects and therapeutic potential of proinsulin C-peptide. Am J Physiol Endocrinol Metab 307: 955-968. DOI: 10.1152/ ajpendo.00130.2014.

Zierath JR, Handberg A, Tally M, Wallberg-Henriksson H (1996). C-peptide stimulates glucose transport in isolated human skeletal muscle independent of insulin receptor and tyrosine kinase activation. Diabetologia 39: 306-313. DOI: 10.1007/BF00418346. 